\title{
Evaluation of Lens Aldose Reductase Inhibitory and Free Radical Scavenging Potential of Fractions of Lonchocarpus cyanescens: Potential for Cataract Remediation
}

\author{
Emmanuel Oladipo Ajani ${ }^{1 *}$, Saheed Sabiu ${ }^{1,2}$, Kuburat Temitope Odufuwa ${ }^{3}$, Taiwo Bashir Ibrahim ${ }^{1}$ and Bamidele \\ Adewale Salau ${ }^{4}$
}

Emmanuel Oladipo

Ajani ${ }^{1 *}$, Saheed Sabiu ${ }^{1,2}$, Kuburat Temitope Odufuwa $^{3}$, Taiwo Bashir Ibrahim ${ }^{1}$ and Bamidele Adewale Salau ${ }^{4}$

'Kwara State University, Malete, Department of Biosciences and Biotechnology, Phytomedicine and Drug Development Laboratory, P. M. B. 1530, Ilorin, Nigeria.

${ }^{2}$ University of the Free State, Faculty of Natural and Agricultural Science South Africa.

${ }^{3}$ Department of Biochemistry,

OlabisiOnabanjoUnivesity,

Remo Campus, Ikenne, Nigeria.

${ }^{4}$ Chemical sciences/Natural sciences,

Redemer's University, Ede, Osun State.

Correspondence

Emmanuel O AJANI, Department of Biosciences and Biotechnology, Kwara State University, Malete,

P. M. B. 1530, llorin, Nigeria.

Phone no: +2348055533192

E-mail: emmanuel.ajani@kwasu.edu.ng; ajaniimman@gmail.com

History

- Submission Date: 22-09-2016;

- Review completed: 10-10-2016;

- Accepted Date: 05-11-2016.

DOI : 10.5530/pj.2017.1.12

Article Available online

http://www.phcogj.com/v9/i1

Copyright

(c) 2016 Phcog.Net. This is an openaccess article distributed under the terms of the Creative Commons Attribution 4.0 International license.

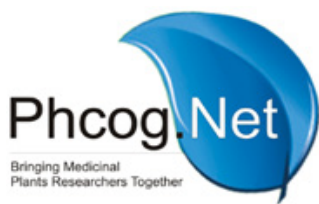

\begin{abstract}
Introduction: Current research effort at discovering effective anticataract agent is focus on evaluating Aldose reductase inhibition (ARI) capacities of medicinal plants and plant extracts. The present study was aimed at investigating the in vitro ARI activity of fractions of Lonchocarpus cyanescens leaves on partially purified AR from goat lens. Methods: Phytochemical constituents of the leaves were screened for using aqueous and methanolic extract while in vitro free radical scavenging and ARI activities of the fractions were evaluated using partially purified aldose reductase. Kinetics of the enzyme in the presence of fractions of the leaves was then compared using Lineweaver-Burk plot. Results: Phenol, flavonoid, tannins and phlobatannins were detected in both extracts. All the fractions inhibited AR significantly but this was strongest with aqueous $\left(\mathrm{IC}_{50}, 0.06 \pm\right.$ $0.02 \mathrm{mM}^{-1}$ and chloroform fractions $\left(\mathrm{IC}_{50}, 0.09 \pm 0.01 \mathrm{mM}^{-1}\right)$. Ethyl acetate, hexane and methanol fraction showed competitive inhibition whereas the aqueous and chloroform fractions showed mixed inhibition with a different $V_{\max }$ and $\mathrm{K}_{\mathrm{m}}$ when compared with DL-glyceraldehyde. All the fractions also showed ${ }^{m}$ antioxidant capacities but this was also strongest with aqueous fraction. Conclusion: The study confirms the ARI and antioxidant capacity of Lonchocarpus cyanescens which may be attributed to its phenolic constituents and whose extraction is solvent dependent. The plant may therefore serve as a base for the development of anticataract agent.
\end{abstract}

Key words: Aldose reductase, Cataract, Free radical, Medicinal plant, Phytochemical constituents.

\section{INTRODUCTION}

Oxygen is a highly reactive atom that is capable of becoming part of potentially damaging molecules commonly called "free radicals." or reactive oxygen species (ROS). Free radicals are capable of attacking the healthy cells of the body, causing them to lose their structure and function. Cell damage caused by free radicals appears to be a major contributor to aging and to degenerative diseases of aging such as cancer, cardiovascular disease, cataracts, immune system decline, and brain dysfunction. ${ }^{1,2}$ Overall, free radicals have been implicated in the pathogenesis of various diseases and particularly diabetes and its secondary complication especially cataract. Cataract is opacity of the lens that interferes with vision, and is the most frequent cause of visual impairment worldwide, especially for the elderly. It is the leading cause of blindness and contributes to $50 \%$ of blindness worldwide. ${ }^{3}$ The only present remedy for cataract is surgery. Free radicals that have been implicated in cataract formation include superoxide anion $\left(\mathrm{O}_{2}^{-)}\right.$, nitric oxide (NO), hydrogen peroxide $\left(\mathrm{H}_{2} \mathrm{O}_{2}\right)$, and hydroxyl radicals $(\mathrm{OH} \cdot)$. Superoxide anionin itself is not highly toxic but it may react with other molecules, such as NO, yielding more reactive compounds. ${ }^{4}$ An excess of $\mathrm{NO}$, produced by inducible nitric oxide synthases (iNOS) upon stimulation, is thought to cause cell injury by nitrosative stress and this may occur in certain diseases. In the eye, $\mathrm{NO}$ contributes to allergic conjunctivitis, ${ }^{5}$ glaucoma, ${ }^{6}$ diabetic retinopathy, and also cataract. ${ }^{8,9} \mathrm{OH}$, , another highly reactive free radical has been shown to contribute to lens crystalline modification. ${ }^{10}$ Fortunately, free radical formation is controlled naturally by various beneficial compounds known as antioxidants. It is when the availability of antioxidants is limited that this damage can become cumulative and debilitating.

In addition to hyperglycemia, diabetes mellitus is usually accompanied by increased generation of free radicals or impaired antioxidant defenses. Several hypothesis have been put forth to explain the genesis of free radicals in diabetes. Forma-

Cite this article : Ajani EO, Sabiu S, Odufuwa KT, Ibrahim TB, Salau BA. Evaluation of Lens Aldose Reductase Inhibitory and Free Radical Scavenging Potential of Fractions of Lonchocarpus cyanescens: Potential for Cataract mediation. Pharmacog J. 2017;9(1):62-9. 
tion of excess superoxide radicals by the mitochondrial transport chain during hyperglycemia has been reported to be the initial factor. ${ }^{11}$ Other major contributing factors include increased glucose flux through the polyol pathway, advanced glycated end products, protein kinase- $\mathrm{C}$ activation and increased flux through the hexosamine pathway. ${ }^{12}$ Of importance to this study is the polyol pathway and especially the role of aldose reductase enzyme in the pathway. Aldose reductase is the first and rate-limiting enzyme in the polyol pathway and reduces glucose to sorbitol utilizing NADPH as a cofactor. Sorbitol is then metabolized to fructose by sorbitol dehydrogenase.$^{13}$ Normally, the polyol pathway represents a minor route of glucose utilization, accounting for $<3 \%$ of glucose consumption. However, in the diabetic state, the activity of this pathway is substantially increased and could represent up to $30 \%$ of total glucose consumption. Sorbitol does not readily diffuse across cell membranes, and the intracellular accumulation of sorbitol has been implicated in the microvascular complications of diabetes such as peripheral neuropathy, nephropathy, retinopathy, and cataracts. ${ }^{12}$

Aldose reductase enzyme and especially its inhibition by aldose reductase inhibitors (ARIs), has been gaining attention over the last years from the pharmaceutical community, as it appears to be a promising pharmacotherapeutic target. Several authors have studied and reported on a number of structurally diverse naturally occurring and synthetic AR inhibitors that have proven to be effective for the prevention of diabetic complications in experimental animals, as well as in clinical trials. ${ }^{14,15}$ Although, some synthetic aldose reductase inhibitors (ARIs) have been developed as drug candidates, however, virtually all have not been successful in clinical trials due to adverse pharmacokinetic properties, inadequate efficacy, and toxic side effects. The use of medicinal plants, plant extracts or plant-derived pure chemicals to treat human ailments is an important alternative therapeutic approach. The medicinal values of plants lie in their component phytochemicals such as alkaloids, tannins, flavonoids and other phenolic compounds, which produce a definite physiological action on the human body. A systematic search for useful bioactivities from medicinal plants is now considered to be a rational approach in nutraceutical and drug research. ${ }^{16}$

Lonchocarpus cyanescens Benth., is a deciduous scan dent shrub. ${ }^{17-19}$ Its common name is West Africa indigo. In Nigeria, the plant is known as 'elu' (Yoruba), 'anunu' (Ibo), 'talaki' (Hausa), 'suru' (Tiv) and 'ebelu' (Edo). ${ }^{20}$ The plant has alternate leaves and flat fruits which are $1-5$ seeded, oblong pod pointed at both ends..$^{19,21,22}$ The aerial parts yield an indigo, which is a useful colourant for cloth dyeing [adire/gara] in West Africa since ancient times ${ }^{23}$ Some of the reported medicinal uses of the plant include poultice to treat skin diseases and ulcers (leaves and roots); possible cure for leprosy (leaves and roots); laxative (leaves); intestinal disorders and dysentery (leaf sap); diarrhea, aphrodisiac, veneral diseases and athritis (decoction of leafy twigs and roots); yaws and sores (ground root). ${ }^{5}$ Bioactivity effects of Lonchocarpus cyanescens have also been demonstrated in its anti-inflammatory, anti-arthritic and its relief on ulcer. ${ }^{20}$ The present study is aimed at evaluating the aldose reductase inhibitory and the free radical scavenging activity of Lonchocarpus cyanescens.

\section{MATERIALS AND METHODS}

Quercetin, 2,2-diphenyl-1-picryl hydrazine (DPPH), TCA, Glacial acetic acid, NADPH, ferrozine, napthylenediamine, dihydrochloride, 1,10-phenanthroline, sulfanilic acid, rutin and 2-mercaptoethanol were obtained, from Sigma-Aldrich Co. (St. Louis, MO, USA). All other solvents and chemicals used were of analytical grade and were obtained from commercial sources.

\section{Plant Materials}

Whole plant of Lonchocarpus cyanescens was collected from a botanical garden in OkeOdo area of Ilorin, Kwara State in July 2015. The plant was identified at the herbarium of Plant Biology, Kwara State University, Malete, Nigeria where a voucher specimen (KS/PLH/ASA4/0/002/101) was deposited. The leaves of the plant were then shade dried for two (2) weeks and then pulversised with a local kitchen blender.

\section{Preparation of Extract and Fractions}

Exactly $100 \mathrm{~g}$ of the pulverized leaves was macerated in $500 \mathrm{ml}$ of methanol for 7 days. It was then sieved over a muslin cloth first and again with filter paper. The residue was again macerated in another $500 \mathrm{ml}$ of methanol for another 7 days and then filtered as above. The filtrates were combined and concentrated using a rotary evaporator under vacuum (model RE, 300 Yamato, Japan). The concentrated product was further dried over a water bath at $40^{\circ} \mathrm{C}$ and weighed. The dried extract was then fractionated by suspending it in distilled water. Hexane was added to the suspension in ratio 1:2, shook well and allowed to stand for about fifteen minutes until two layers were formed. The hexane layer was removed and more hexane was added to the aqueous layer. The process was repeated once, and then a colorless hexane layer was seen. The two hexane layers were combined and dried to obtain the hexane fraction. The procedure was repeated with the aqueous layer using chloroform and ethyl acetate respectively. Each fraction obtained including the aqueous fraction was then collected and dried. Aqueous fraction was dried by lyophilizing for a total of 72 hours. The fractions obtained with othersolvents were recovered using rotary evaporator under vacuum. The evaporation process was conducted at $40^{\circ} \mathrm{C}$ to minimize any possible degradation of the phytochemicals in the samples. The weight of the dried fractions were calculated and the samples were then stored in a desiccator for further use.

\section{Isolation and Partial Purification of Goat Eye Lenses}

Eye ball was removed from goat immediately after sacrifice and stored in ice-cold container. Lenses were removed by lateral incision of the eye, washed with ice-cold distilled water and kept cold. The lenses were homogenized in 10 volumes of $100 \mathrm{mM}$ ice- cold potassium phosphate buffer, pH6.2 and centrifuged at 15,000 xg for 30 minutes at $4^{\circ} \mathrm{C}$. The resulting supernatant was used as the source of aldose reductase. Saturated ammonium sulphate $(100 \%)$ was added to the supernatant from the homogenate to reach $40 \%$ saturation and then allowed to stand for $15 \mathrm{~min}$ with occasional stirring to ensure the completeness of precipitation. It was then centrifuged and the precipitate was discarded. The same procedure was repeated for the resulting supernatant using 50\% and 75\% ammonium sulphate saturations. The final supernatant was used as the partially purified aldose reductase.

\section{Aldose Reductase Assay}

The method of Hayman and Kinoshita ${ }^{24}$ was used to assay for aldose reductase (AR) activity. Enzyme specific activity was calculated as IU/mg protein and this was defined as activity of the enzyme that can produce $1 \mu \mathrm{mol} \mathrm{NADP}{ }^{+}$from NADPH in 1 min. $^{25}$

\section{Inhibition Study}

Varied concentrations $(0.4-2.8 \mathrm{mg} / \mathrm{ml})$ of the methanolic extract of the leaves and its fractions were prepared in triplicate. Exactly $100 \mu \mathrm{l}$ of concentration prepared was then added to the assay mixture and incubated for 5-10 minutes. The reaction was initiated with the addition of NADPH. The absorbance was then read at $340 \mathrm{~nm}$ at the beginning and at the end of 30 minutes. The per cent inhibition (\%ARI) of the extract/ fraction was then calculated as: 


$$
\begin{aligned}
& \Delta \text { absorbance (negative control) - } \\
& \% \mathrm{ARI}=\frac{\Delta \text { absorbance }(\text { fraction })}{\Delta \text { absorbance }(\text { negative control })} \times 100
\end{aligned}
$$

The AR activity in the absence of inhibitor was considered as $100 \%$. The concentration of each test sample that gives $50 \%$ inhibition (IC ) was then estimated. A negative control was prepared using 5\% DMSSO in phosphate buffer (pH6.2).

\section{Determination of Kinetic Parameters}

The kinetic studies of inhibitory activity of the fraction against aldose reductase of different fractions were analyzed using the Line weaverBurk plot.

\section{Estimation of Lens Protein Concentration}

The protein determination was carried out using the Stoschck, ${ }^{26}$ modified method of Lowry et al. ${ }^{27}$

\section{Assay for Free Radical Scavenging Activity DPPH Radical Scavenging Assay}

The DPPH (1, 1- diphenyl-2-picryl hydrazyl) radical scavenging method was used to evaluate the antioxidant property of the plant. The antioxidant activity of each sample was expressed in terms of $\mathrm{IC}_{50}$, and this was calculated from the graph of inhibition percentage against fraction concentration. The assay was carried out according to the method of Hemalatha et al.,. ${ }^{28} \mathrm{DPPH}(0.1 \mathrm{mM})$ was prepared in methanol and $1.0 \mathrm{ml}$ of its solution was mixed with $1.0 \mathrm{ml}$ of extract/fractions prepared in methanol at different concentrations $(20,40,60,80$ and $100 \mu \mathrm{g} / \mathrm{ml})$. The mixture was shaken well and incubated at room temperature for 30 minutes and absorbance was measured at $517 \mathrm{~nm}$ using a UV- spectrophotometer. All the experiments were performed in triplicate and the mean was taken. Scavenging activity was calculated from control sample absorbance using the following equation:

$\mathrm{DPPH}$ - Scavenging capacity $(\%)=\left[\left(\mathrm{A}^{0}\right.\right.$ control $-\mathrm{A}^{0}$ sample $/ \mathrm{A}^{0}$ control $\left.) \times 100\right]$

Ascorbic acid was used as positive control. $\mathrm{IC}_{50}$ values (concentration of extract/fraction required to reduce $50 \%$ of DPPH radical) were estimated from the graph and compared.

\section{Metal Chelating Activity}

This was carried out following the method of Decker and Welch. ${ }^{29}$ The extract/fraction $(0.5 \mathrm{~g})$ was mixed with $\mathrm{FeCl}_{3}(2 \mathrm{mM})$ and ferrozine $(0.2 \mathrm{ml})$ in a test tube, and the total volume was diluted with methanol ( $2 \mathrm{ml})$. The mixture was vigorously shaken and left standing for 10 minutes at room temperature. The absorbance of the solution was measured spectrophotometrically at $562 \mathrm{~nm}$ after the mixture had reached equilibrium. EDTA was used as positive control and the percent inhibition of ferrozine- $\mathrm{Fe}^{2+}$ complex was calculated using the formula stated below.

- $\quad$ Percent Scavenging $=\left[\left(\mathrm{A}^{0}\right.\right.$ control $-\mathrm{A}^{0}$ sample $) / \mathrm{A}^{0}$ control $] \times 100$

- Where: $\mathrm{A}^{0}$ control = absorbance of ferrozine- $\mathrm{Fe}^{2+}$ complex

$\mathrm{A}^{0}$ sample $=$ absorbance of test compound

\section{Hydroxyl Radical Scavenging Activity}

This was carried out according to the method described by Yu et al., ${ }^{30}$ The reaction medium was made up of $60 \mu \mathrm{l}$ of $1 \mathrm{mM} \mathrm{Fecl}_{3}, 90 \mu \mathrm{l}$ of $1 \mathrm{mM}$ 1,10-phenanthroline, $2.4 \mathrm{ml}$ of $0.2 \mathrm{M}$ phosphate buffer ( $\mathrm{pH} 7.8$ ), $150 \mu \mathrm{l}$ of $0.17 \mathrm{M} \mathrm{H}_{2} \mathrm{O}_{2}$, and $1.5 \mathrm{ml}$ of various concentration of each fractions/ methanol extract. Reaction mixture was kept at room temperature for $5 \mathrm{~min}$ incubation and absorbance was then measured at $560 \mathrm{~nm}$ using spectrophotometer. The concentration of the individual sample required to neutralize $50 \%$ hydroxyl radicals were considered as $\mathrm{IC}_{50}$ values.

\section{Nitric Oxide Radical Scavenging Activity}

Method previously described by Garrat ${ }^{31}$ was used for estimating nitric oxide radical scavenging activity. The reaction mixture containing $2 \mathrm{ml}$ of $10 \mathrm{mM}$ sodium nitroprusside, $0.5 \mathrm{ml}$ of phosphate buffer saline $(\mathrm{pH} 7.4)$ and $0.5 \mathrm{ml}$ of plant extract/fraction was incubated at $25^{\circ} \mathrm{C}$ for $2 \mathrm{hr} 30 \mathrm{~min}$. After incubation time, $0.5 \mathrm{ml}$ of reaction mixture was mixed with $1 \mathrm{ml}$ of sulfanilic acid reagent (33\% in $20 \%$ glacial acetic acid) and incubated for $5 \mathrm{~min}$. This was followed by addition of $1 \mathrm{ml}$ napthylenediamine dihydrochloride $(0.1 \% \mathrm{w} / \mathrm{v})$. The mixture was incubated at room temperature for $30 \mathrm{~min}$. The absorbance was measured at $560 \mathrm{~nm}$ using UV-VIS spectrophotometer. The amount of sample required to scavenge $50 \%$ nitric oxide radicals generated in the control set were calculated as $\mathrm{IC}_{50}$.

\section{Hydrogen Peroxide Scavenging Activity}

The assay method described by Ruch et al., ${ }^{32}$ was used to determine the ability of plant extracts/fraction to scavenge hydrogen peroxide. A solution of hydrogen peroxide $(40 \mathrm{mM})$ was prepared in phosphate buffer ( $\mathrm{pH}$ 7.4). The extract/fraction prepared in distilled water was mixed with $0.6 \mathrm{ml}$ of hydrogen peroxide solution $(40 \mathrm{mM})$. The absorbance of hydrogen peroxide at $230 \mathrm{~nm}$ was determined after 10 min against a blank solution containing plant extract/fraction in phosphate buffer without hydrogen peroxide. The absorbance of hydrogen peroxide (40 $\mathrm{mM}$ ) without plant extract was considered as control (100\%). The concentration of plant extract/fraction required to scavenge $50 \%$ hydrogen peroxide was calculated as $\mathrm{IC}_{50}$.

\section{Reducing Power Assay}

This was determined by the previously described method. ${ }^{33}$ The reaction mixture containing $0.75 \mathrm{ml}$ of various concentrations of plant extract/ fraction, $0.75 \mathrm{ml}$ of phosphate buffer $(0.2 \mathrm{~N}, \mathrm{pH} 6.6)$ and $0.75 \mathrm{ml}$ of potassium hexacyanoferrate $\left[\left(\mathrm{K}_{3} \mathrm{Fe}(\mathrm{CN})_{6}\right](1 \% \mathrm{w} / \mathrm{v})\right.$ was incubated at $50^{\circ} \mathrm{C}$ in water bath for $20 \mathrm{~min}$. The reaction was stopped by the addition of $0.75 \mathrm{ml}$ trichloroacetic acid (10\%) and then centrifuged for $10 \mathrm{~min}$ at $800 \mathrm{rpm}$. The supernatant $(1.5 \mathrm{ml})$ of the individual reaction mixture was collected in different clean tubes and was mixed with $1.5 \mathrm{ml}$ of distilled water followed by addition of $0.1 \mathrm{ml}$ ferric chloride $(0.1 \% \mathrm{w} / \mathrm{v})$ and kept for $10 \mathrm{~min}$. The absorbance of reaction mixture was measured at $700 \mathrm{~nm}$ as the reducing power. The absorbance of control was considered as $100 \%$ of $\mathrm{Fe}^{3+}$ ions and $\mathrm{IC}_{50}$ values were determined as the concentration of plant extract/fraction required to inhibit $50 \%$ reduction of $\mathrm{Fe}^{3+}$ ions.

\section{Phytochemical Screening}

The methanolic and aqueous extracts of the plant was subjected to different chemical tests for the detection of the plant phytoconstituents using standard procedures. ${ }^{34-36}$

\section{Statistics}

The experimental results obtained were expressed as mean values of three replicates. Linear regression analysis was used to calculate the $\mathrm{IC}_{50}$ values. Data are expressed as mean \pm SEM of 3 replicates and were subjected to one way analysis of variance (ANOVA) followed by Duncan Multiple Range Test to determine significant differences in all the parameters. Values were considered significantly different at $\mathrm{p}<0.05$.

\section{RESULT}

Preliminary phytochemical screening carried out on the methanolic and aqueous extracts of Lonchocarpus cyanescens revealed the presence of 
phenols, phlobatannins, flavonoids and tannins in both extracts. Saponin, cardiac glycosides, quinones and alkaloids were however found only in the aqueous extract (Table 1). When the yield of the fractions were compared (Table 2), aqueous fractionyield was the highest (18.20\%) while chloroform fraction yield was the lowest (5.10\%).

Comparing the effect of incubation of the lens aldose reducatse, results obtained (Figure 1) indicates that all the fractions inhibited lens aldose reductase activity to various degree. The figure showed that, the percentage inhibition increases with the concentration of the fraction until a peak was reached after which further increase in concentration of sample does not result in increase in percentage aldose reductase inhibition (except for hexane fraction). Table 3 is the profile of the concentration of individual fraction required to achieve $50 \% \mathrm{AR}$ inhibition. Both aqueous and methanolic fractions showed strong aldose reductase inhibition with $\mathrm{IC}_{50}$ of $0.06 \pm 00.02$ and $0.09 \pm 0.01 \mathrm{mg} / \mathrm{ml}$ respectively. All other fractions showed mild aldose reductase inhibition with ethylacetate fraction showing the weakest inhibition with $\mathrm{IC}_{50}$ of $2.29 \pm 0.03 \mathrm{mg} / \mathrm{ml}$. In this study, the Kinetic study was performed for all the fractions in order to understand exactly the mode of inhibition. Data from the study indicates that ethyl acetate, hexane and methanol fraction showed competitive inhibition. The Lineweaver-Burk plot (Figure 2) and the kinetic parameters obtained (Table 4) showed that although the aldose reductase $\mathrm{V}_{\max }$ obtained when these fractions were incubated with Dl-glyceraldehyde $(0.136 \pm 0.041,0.066 \pm 0.014$ and $0.052 \pm 0.023 \mu \mathrm{m} \mathrm{NADPH}$ oxidised/hr/100 mg protein for ethyl acetate, hexane and methanol respectively) were significantly $(\mathrm{p}<0.05)$ reduced from the control value $(0.830 \pm 0.031 \mu \mathrm{m} \mathrm{NADPH}$ oxidised/hr/100 mg protein $)$, the $\mathrm{K}_{\mathrm{m}}$ were not different significantly ( $\mathrm{p}>0.05)$ different from that of the substrate glyceraldehyde $\left(6.613 \pm 0.642,6.313 \pm 0.052,5.520 \pm 0.619 \mathrm{mM}^{-1}\right.$ for ethyl acetate, hexane and methanol respectively). In aqueous and chloroform fraction, the valueof the $\mathrm{V}_{\max }(0.136 \pm 0.042$ and $0.038 \pm 0.012 \mu \mathrm{m}$ $\mathrm{NADPH}$ oxidised/hr/100 mg protein respectively) and $\mathrm{K}_{\mathrm{m}}(17.900 \pm$ 0.642 and $0.992 \pm 0.031 \mathrm{mM}^{-1}$ obtained for aqueous and chloroform fraction respectively) differs significantly $(\mathrm{p}<0.05)$ when compared with DL-glyceraldehyde value $(0.830 \pm 0.031 \mu \mathrm{m} \mathrm{NADPH}$ oxidised/hr/100 mg protein for $\mathrm{V}_{\max }$ and $6.413 \pm 0.012 \mathrm{mM}^{-1}$ for $\mathrm{K}_{\mathrm{m}}$ ) which indicates that these fraction showedmixed inhibition.

Table 5 is the result of the free radical scavenging activities of the fractions of Lonchocarpus cyanescens. Strongest DPPH scavenging activity was shown by the aqueous fraction with an $\mathrm{IC}_{50}$ of $0.050 \pm 0.009 \mathrm{mg} / \mathrm{ml}$ ). All other fractions showed mild DPPH scavenging activity with hexane fraction showing the weakest $\left(\mathrm{IC}_{50}, 0.139 \pm 0.031 \mathrm{mg} / \mathrm{ml}\right)$. Similarly, the metal chelating activity was highest with aqueous fraction $(88.6 \%)$ and weakest with hexane fraction $(18.1 \%)$. Results of the hydroxyl radical scavenging activity also showed that the $\mathrm{IC}_{50}$ of $0.664 \pm 0.039 \mathrm{mg} / \mathrm{ml}$ obtained with aqueous fraction was the lowest and was followed by $\mathrm{IC}_{50}$ of $0.861 \pm 0.098 \mathrm{mg} / \mathrm{ml}$ showed by methanol fraction. Hexane fraction showed the least hydroxyl radical scavenging activity with $\mathrm{IC}_{50}$ of 1.963 $\pm 0.041 \mathrm{mg} / \mathrm{ml}$. A similar pattern was seen when the hydrogen peroxide and NO scavenging activities were compared. Result of the reducing power activity also showed that the aqueous fraction elicits the highest reducing power $\left(\mathrm{IC}_{50}, 0.211 \pm 0.003 \mathrm{mg} / \mathrm{ml}\right)$ while the hexane fraction also elicits the least reducing power $\left(\mathrm{IC}_{50}, 0.613 \pm 0.001 \mathrm{mg} / \mathrm{ml}\right)$.

\section{DISCUSSION}

Preliminary qualitative test is useful in the detection of plant bioactive principles and subsequently may lead to drug discovery and development. ${ }^{37}$ Our study indicates that $L$. cyanescens leaves contain different phytochemicals with diverse biological properties. In a previous study with L. cyanescens, Dorcas et al., ${ }^{20}$ reported the presence of phlobatannins (methanolic leave extract), steroid (hexane leave extract), flavonoid
Table 1: Classes of phytochemicals Detected in of Lonchocarpus cyanescens Leaves in aqueous and methanolic extracts

\begin{tabular}{ccc}
\hline $\begin{array}{c}\text { Phytochemical } \\
\text { constituents' }\end{array}$ & Aqueous extract & Methanolic extract \\
\hline Phenols & + & + \\
Phlobatannins & + & + \\
Tannins & + & + \\
Flavonoids & + & + \\
Saponins & + & - \\
Alkaloids & + & - \\
Anthocyanins & - & - \\
Cardiac glycosides & + & - \\
Terpenoids & - & - \\
Quinones & + & - \\
\hline
\end{tabular}

Note: + denotes detected and - denotes not detected.

Table 2: Yield of extract/ fraction of Lonchocarpus cyanescens Leaves ( $n=3$ \pm SEM)

\begin{tabular}{cc}
\hline Extract/ Fraction & Yield (\%) \\
\hline Methanol & 11.51 \\
Aqueous & 18.20 \\
Ethylacetate & 16.11 \\
Hexane & 6.71 \\
Chloroform & 5.10 \\
\hline
\end{tabular}

Table 3: $\mathrm{IC}_{50}(\mathrm{mg} / \mathrm{ml})$ of fractions of Lonchocarpus cyanescens leaves on aldose reductase activity

\begin{tabular}{cc}
\hline Fraction & $\mathrm{IC}_{50}(\mathrm{mg} / \mathrm{ml})$ \\
\hline Chloroform & $1.03 \pm 0.01$ \\
Methanol & $0.09 \pm 0.01$ \\
Ethyl acetate & $2.29 \pm 0.03$ \\
Aqueous & $0.06 \pm 0.02$ \\
Hexane & $1.17 \pm 0.02$ \\
\hline
\end{tabular}

- All values are expressed as mean $\pm S D, n=3$.

- Values in the same column with similar superscripts are not significantly different from each other.

Table 4: Kinetics parameters of aldose reductase enzyme in the presence of different fractions of Lonchocarpus cyanescensleaves

\begin{tabular}{|c|c|c|}
\hline Extract/fraction & $\begin{array}{c}\text { Vmax } \\
(\mu \mathrm{m} \text { NADPH } \\
\text { oxidised } / \mathrm{hr} / 100 \mathrm{mg} \\
\text { protein) }\end{array}$ & $\mathrm{Km} \times 10^{-3} \mathrm{mM}$ \\
\hline DL- glyceraldehyde & $0.830 \pm 0.031^{\mathrm{a}}$ & $6.313 \pm 0.012^{\mathrm{a}}$ \\
\hline DL- glyceraldehyde + methanol & $0.052 \pm 0.023^{\mathrm{b}}$ & $5.520 \pm 0.619^{\mathrm{a}}$ \\
\hline DL- glyceraldehyde + chloroform & $0.038 \pm 0.012^{c}$ & $0.992 \pm 0.031^{c}$ \\
\hline DL- glyceraldehyde + hexane & $0.066 \pm 0.014^{\mathrm{d}}$ & $6.313 \pm 0.052^{\mathrm{a}}$ \\
\hline DL- glyceraldehyde + ethylacetate & $0.139 \pm 0.032^{\mathrm{e}}$ & $6.163 \pm 0.137^{\mathrm{a}}$ \\
\hline DL- glyceraldehyde + aqueous & $0.136 \pm 0.042^{\mathrm{e}}$ & $17.900 \pm 0.642^{\mathrm{d}}$ \\
\hline
\end{tabular}

- All values are expressed as mean $\pm S D, n=3$.

- Values in the same column with similar superscripts are not significantly different from each other. 
Table 5: Free radical scavenging activity of extract and fractions of Lonchocarpus cyanescens leaves

\begin{tabular}{ccccccc}
\hline Extract/Fractions & $\begin{array}{c}\text { DPPH IC } \\
(\mathbf{m g} / \mathbf{m l})\end{array}$ & $\begin{array}{c}\text { Metal chelating } \\
\text { activity }\end{array}$ & $\begin{array}{c}\mathrm{OH} \mathrm{IC}_{50} \\
(\%)\end{array}$ & $\begin{array}{c}\mathrm{H}_{2} \mathrm{O}_{2} \mathrm{IC}_{50} \\
(\mathbf{m g} / \mathbf{m l})\end{array}$ & $\begin{array}{c}\text { Reducing power IC } \\
(\mathbf{m g} / \mathbf{m l})\end{array}$ & $\begin{array}{c}\mathrm{NO} \mathrm{IC}_{50} \\
(\mathrm{mg} / \mathrm{ml})\end{array}$ \\
\hline Methanol & $0.089 \pm 0.021^{\mathrm{a}}$ & 51.8 & $0.861 \pm 0.098^{\mathrm{a}}$ & $0.516 \pm 0.001^{\mathrm{a}}$ & $0.401 \pm 0.011^{\mathrm{a}}$ & $1.011 \pm 0.021^{\mathrm{a}}$ \\
Aqueous & $0.050 \pm 0.009^{\mathrm{b}}$ & 88.6 & $0.664 \pm 0.039^{\mathrm{b}}$ & $0.603 \pm 0.012^{\mathrm{b}}$ & $0.211 \pm 0.003^{\mathrm{b}}$ & $0.538 \pm 0.009^{\mathrm{b}}$ \\
Ethylacetate & $0.988 \pm 0.054^{\mathrm{a}}$ & 39.6 & $0.974 \pm 0.063^{\mathrm{a}}$ & $0.905 \pm 0.001^{\mathrm{c}}$ & $0.361 \pm 0.008^{\mathrm{c}}$ & $1.260 \pm 0.014^{\mathrm{c}}$ \\
Chloroform & $0.109 \pm 0.061^{\mathrm{a}}$ & 28.3 & $1.789 \pm 0.069^{\mathrm{c}}$ & $1.726 \pm 0.004^{\mathrm{d}}$ & $0.332 \pm 0.007^{\mathrm{c}}$ & $1.968 \pm 0.100^{\mathrm{d}}$ \\
Hexane & $0.139 \pm 0.031^{\mathrm{a}}$ & 18.1 & $1.963 \pm 0.041^{\mathrm{c}}$ & $1.631 \pm 0.001^{\mathrm{d}}$ & $0.613 \pm 0.011^{\mathrm{d}}$ & $2.613 \pm 0.091^{\mathrm{e}}$ \\
\hline
\end{tabular}

- All values are expressed as mean $\pm S D, n=3$.

- Values in the same column with similar superscripts are not significantly different from each other.

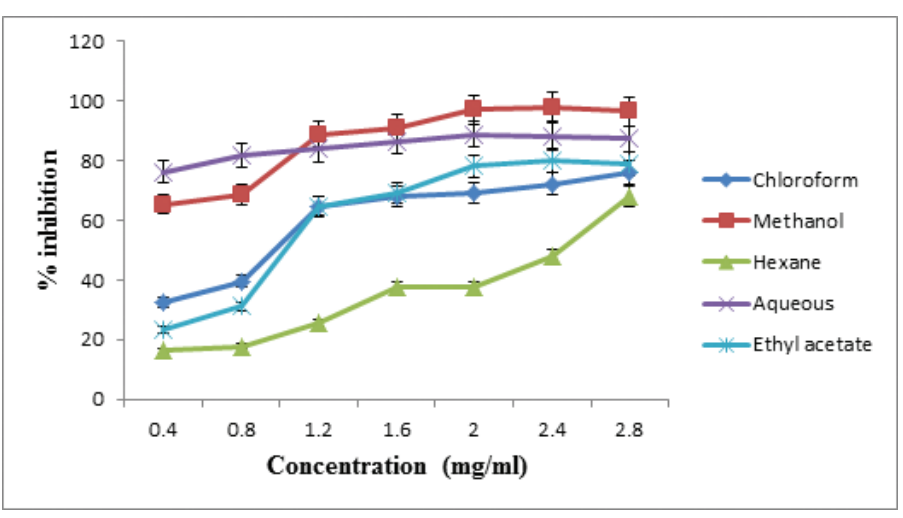

Figure 1: Inhibitory effect of fractions of Lonchocarpus cyanescens Leaves on the specific aldose reductase activity.

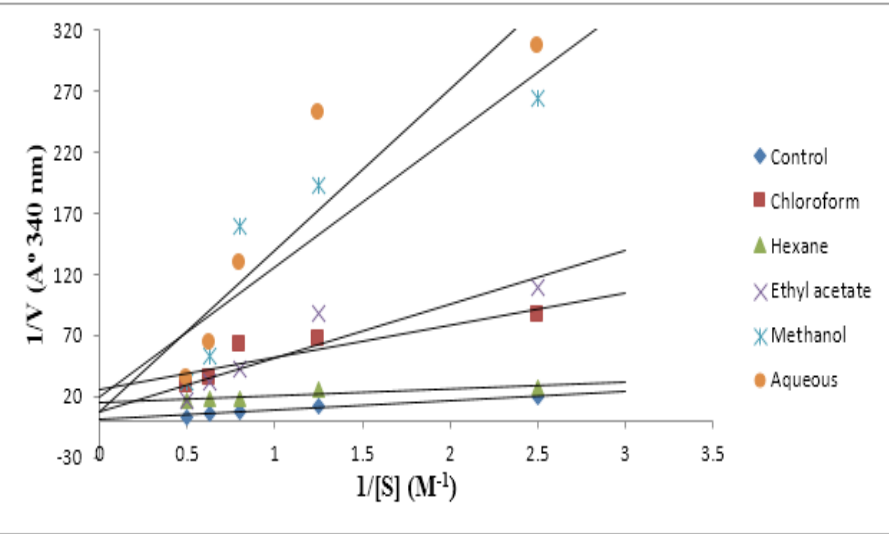

Figure 2: Lineweaver-Burk plot showing the inhibitory effect of fractions of Lonchocarpus cyanescens Leaves on the aldose reductase activity.

(methanolic leave residue), saponin (methanolic stem extract), tannin and cardiac glycoside (hexane stem extract), phlobatanin (methanolic root extract) and terpenoid (methanolic stem interpahase). In the present study, we detected the presence of phenol, phlobatannin, flavonoid and tannin in both aqueous and methanolic leave extract of the plant while saponin, alkaloids, cardiac glycosides and quinones were detected only in the aqueous extract. More of the phytochemicals were detected in the aqueous extract than the methanolic extract indicating that the efficacy of solvents in extracting the bioactive principles of the plant may correlate with solvent polarity and that it is highest in the most polar solvent. The presence of these phytochemicals in the leaves of L. cyanescens may form the basis for its inclusion in Traditional Medical Practices. ${ }^{38-40}$ Phenolic compounds are especially common in leaves, flowering tissues and woody parts, such as stems and barks. Reports have implicated phenolic compounds as having health beneficial properties. This is because the compound is able to inhibit aldose reductase and xanthine oxidase enzymes. ${ }^{41}$ Reports in the literature indicates that the most widely used solvents for extracting phenolic compounds are water, ethanol, methanol, acetone, and their water mixtures. ${ }^{42-44}$ Thepresent study is in agreement with these reports.

When the yields of the fractions were compared, result from the present study indicates that the yield of the aqueous fraction was the highest followed by methanol, ethylacetate, chloroform and hexane in that order. The result suggests that the major phytochemicals in L. cyanescens, leaves were mostly high in polarity and soluble in water. This is similar to the observation of Mohd Farhan et al., ${ }^{45}$ with Orthosiphon stamineus. Although both water and methanol contain hydroxyl group that can form hydrogen bonding with the solute, water may be more effective in extracting the solute because it has higher polarity and shorter chain. ${ }^{46}$ These characteristics of water improved its capability to extract the polar compounds. This thus explains the significant difference observed between water and methanol fraction yield. The difference in yields for other solvents may be due to other factors including phytochemicals in plants, extraction temperature, extraction time and solvent to solid ratio. Result of this study also indicates that all the fraction of L. cyanescens leaves investigated in this study this study showed significant aldose reductase inhibitory activity The ARI capacity was seen to be strongest with aqueous and methanolic fraction but weakest with ethylacetate fraction. Chloroform and hexane fraction showed mild AR inhibitory activity. In an attempt to develop potent, safe, and new ARI agents from natural sources, many plant materials and isolated phytoconstituents have been tested for ARI activity in both in vivo and in vitro models. Halder et $a l^{25}$ reported on aldose reductase inhibiting activity of few natural products such as root of Salacia oblonga, Salviae multiorrhizae, Glycerrhiza uralensis, Radix astragali and puerarin. Some other studies that have also reported on aldose reductase inhibition capacities of plant products are Ajani et al, ${ }^{47}$ Jung et al..${ }^{48}$ Patel et al. ${ }^{15,49}$ Reports from these studies strengthen our study because we have reported in this study that L. cyanescens also contains phenol, flavonoid and other phytochemicals. We have also reported in this study that the $\mathrm{IC}_{50}$ of fractions of $L$. cyanescens ranged from 0.06 (aqueous fraction) to $1.17 \mathrm{mg} / \mathrm{ml}$ (hexane fraction).

The detection of phenols and flavonoids as reported in this study suggest that the aldose reductase inhibitory action of $L$. cyanescens may be due to these phytoconstituents. Phenolic compounds are one of the most widely occurring groups of phytochemicals and are of considerable physiological and morphological importance in plants. ${ }^{41,50}$ Flavonoids another antioxidant detected in the leaves of $L$. cyanescens are commonly ingested from fruits and vegetables in the diet, although they have no nutritive value, they are capable of exerting various pharmacological activities, including antioxidative, superoxide- scavenging, and aldose reductase 
inhibitory activity. ${ }^{49}$ Several flavonoids, such as quercitrin, guaijaverin and desmanthin have been tested and proven for their inhibitory activity against aldose reductase. ${ }^{51} \mathrm{~A}$ previous study by Mutiu and Theophilus ${ }^{52}$ reported that ethanol leaf extract of L. cyanescens possessed hypoglycaemic effect, and that one of the mechanisms by which this extract elicited its hypoglycaemic property may be through the inhibition of diabetesrelated enzymes (pancreatic $\alpha$-amylase and intestinal $\alpha$-glucosidase) activities. In the present study, we also reported that the leaves extract of $L$. cyanescens may be effective in preventing the secondary diabetic complication particularly cataract, and that this effect may be due to the ability of the plant to inhibit aldose reductase activity.

In order to elucidate the mode of inhibition of aldose reductase enzyme by $L$. cyanescens, the kinetic study was performed for the entire fraction. Effect of different fractions on rat lens aldose reductase activity in Lineweaver-Burk plot using DL glyceraldehyde as a substrate was made between 1 /velocity vs $1 / \mathrm{DL}$-glyceraldehyde. Data obtained in the study suggest that the aldose reductase inhibitory compounds present in L. cyanescens leaves extract/fractions can interact and inhibit lens aldose reductase enzyme. Kinetic study performed to understand the type of inhibition suggest that these compounds can interact and inhibit AR enzyme in both competitive and un-competitve manner. At the macroscopic level, the effect of competitive inhibition is to increase the substrate concentration required to achieve a given reaction velocity; in other words, to raise the $\mathrm{K}_{\mathrm{m}}$. The $\mathrm{V}_{\max }$ is unchanged, however. Mixed inhibition is a type of reversible inhibition which combines the effects of both competitive and uncompetitive inhibition. The inhibitor can bind either the enzyme or the enzyme-substrate complex and in either case will form an inactive complex. The inhibitor does not bind to the substrate binding site and therefore is not a substrate analogue. The value of $\mathrm{V}_{\max }$ will go down; the $\mathrm{Km}$ can go up or down. ${ }^{53}$ The data obtained suggest that aqueous fraction had significant activity against aldose reductase enzyme, this may be due to the presence of the phenol and flavonoid contents. A lower $\mathrm{K}_{\mathrm{m}}$ corresponds to a higher affinity. The presence of an uncompetitive inhibitor actually increases the affinity of the enzyme for the substrate. Since the inhibitor binds the E-S complex, the inhibitor decreases the concentration of the E-S. ${ }^{53}$ Despite their rarity in drug discovery programs, uncompetitive inhibitors could have dramatic physiological consequences. As the inhibitor decreases the enzyme activity, there is an increase in the local concentration of substrate. Without a mechanism to clear the buildup of substrate, the potency of the uncompetitive inhibitor will increase.

Reactive oxygen species (ROSs) are known to damage cellular membranes by inducing lipid peroxidation. They also can damage DNA, proteins, lipids and chlorophyll. ${ }^{54}$ The most popular ROS are. $\mathrm{O}_{2}^{-}$(superoxide radical), $\mathrm{H}_{2} \mathrm{O}_{2}$ (hydrogen peroxide) and . $\mathrm{OH}$ (hydroxyl radical) originating from one, two or three electron transfers to dioxygen $\left(\mathrm{O}_{2}\right)$. Under physiological conditions. $\mathrm{O}_{2}^{-}$is not very reactive against the biomolecules of the cell and in aqueous solutions at neutral or slightly acidic $\mathrm{pH}$ disproportionates to $\mathrm{H}_{2} \mathrm{O}_{2}$ and $\mathrm{O}_{2} \cdot \mathrm{H}_{2} \mathrm{O}_{2}$ is relatively stable and not very reactive, electrically neutral ROS, but is very dangerous because it can pass through cellular membranes and reaches cell compartments far from the site of its formation. ${ }^{11}$ Free radicals can initiate the oxidation of bio molecules, such as protein, lipid, amino acids and DNA which will lead to cell injury and can induce numerous diseases. Cataract formation has been attributed to oxidative stress triggered by these reactive oxygen species (ROS). All the fractions investigated in this study showed free radical scavenging activity. Data from the study further revealed that the aqueous fraction has a greater reducing power and was more efficacious than all other fractions in scavenging free radicals and also as a metal chelator. Plants produce a very diverse group of secondary metabolites with antioxidant potential. A report by Catherine et al..$^{55}$ indicated that Recent studies have shown that many dietary polyphenolic constituents derived from plants are more effective antioxidants in vitro than vitamins $\mathrm{E}$ or $\mathrm{C}$ many dietary polypenolic constituents derived from plants are more effective antioxidants in vitro than vitamin $\mathrm{E}$ and $\mathrm{C}$ and thus might contribute significantly to protective effect in vivo. studies have shown that many dietary polyphenolic constituents derived from plants are more effective antioxidants in vitro than vitamins $\mathrm{E}$ or $\mathrm{C}$, and thus might contribute significantly to the protective effects in vivo. The antioxidant activity of polyphenols has been attributed to their ability to scavenge free radicals (which allow them to act as reducing agents and hydrogen or electron donor) or chelate metal cations. ${ }^{41,50,56}$ Zhang et al., ${ }^{57}$ reported that the presence of electron-donating and electron-withdrawing substituents in the ring structure of phenolics as well as the number and arrangement of the hydroxyl groups determines their antioxidant potential. Our result alsosuggests that the free radical scavenging capacities of the antioxidants present in L. cyanescens is correlated with the solvent employed in the fractionation. This therefore indicates that the antioxidant potential of compounds varies with the polarities of the solvents. This observation agrees with the report of Moure et al. ${ }^{58}$ Reducing power is associated with antioxidant activity and may serve as a significant reflection of the antioxidant activity. Compounds with reducing power indicate that they are electron donors and can reduce the oxidized intermediates of lipid peroxidation processes, so that they can act as primary and secondary antioxidants. ${ }^{59}$

\section{CONCLUSION}

Result of this study indicates that the leaves of L. cyanescens has a strong aldose reductase and free radical scavenging activity against DPPH, $\mathrm{H}_{2} \mathrm{O}_{2}, \mathrm{NO}, \mathrm{O}_{2}, \mathrm{OH}$. These activities, the study revealed is more concentrated in the aqueous fraction indicating that the efficacy of $L$. cyanescens extract in inhibiting aldose reductase enzyme is dependent on extractive solvents. In order to effectively utilized the plant as a base for anticataractogenin agent, there is need to further isolate and characterize the antioxidant constituents responsible for this action and to confirm these observed results in in vivo studies. It is also important to determine the toxicological implication of the plant and to identify the bioactive compound responsible for these observed actions. This is the focus of on going study in our laboratory.

\section{ACKNOWLEDGEMENT}

The authors declare that there are no conflicts of interest.

\section{CONFLICT OF INTEREST}

The authors are grateful to Mr. Ajibade of Biochemistry Laboratory, Department of Biological Sciences, Landmark University, Omuaran for the kind assistance received and also to our research students who participated in the study.

\section{REFERENCES}

1. Cadenas E, Davies AJ. Mitochondrial free radical generation, oxidative stress and ageing. Free Rad Biool Med. 2000;29(3):222-30. http://dx.doi.org/10.1016/ S0891-5849(00)00317-8

2. Prasad MP, Ashwin R. In vitro antioxidant assay of citrus species using DPPH method. Indian Journal of Advances in Plant Research (IJAPR). 2014;1(4):01-93.

3. Haque SE, Gilani KM. Effect of Ambroxol, Spirulina and Vitamin E in naphthalene induced cataract in female rats. Ind J Physiol Pharmacol. 2005;49(1):57-64

4. Graham A, Hogg N, Kalyanaraman B, O'Leary V, Darley-Usmar V, Moncada S. Peroxynitrite modification of low-density lipoprotein leads to recognition by the macrophage scavenger receptor. FEBS Lett. 1993;330(2):181-5. http://dx.doi. org/10.1016/0014-5793(93)80269-Z

5. Meijer F, Van Delft JL, Garrelds IM, Van Haeringen NJ, Kijlstra A. Nitric oxide plays a role as a mediator of conjuctival edema in experimental allergic conjunctivitis. Exp Eye Res. 1996;62(4):359-65. http://dx.doi.org/10.1006/exer.1996.0041 
6. Scneemann A, Dicstra BG, van den Berg TJ, Kamphius W, Hoyng PF. Nitric oxide/guanylate cyclase pathways and flow in anterior perfusion. Graefes Arch Clin Exp Ophtahamol. 2002;240(11):936-41. http://dx.doi.org/10.1007/s00417002-0559-7

7. Tsai DC, Chiou SH, Lee FL, Chou CK, Chen SJ, Peng CH, et al. Possible involvement of nitric oxide in the progression of diabetic retinopathy. Ophthalmologica. 2003;217:342-6. http://dx.doi.org/10.1159/000071349

8. Ito $Y$, Nabekura T, Takeda M, Nakao M, Terao M, Hori R, et al. Nitric oxide participates in cataract development in selenite-treated rats. Curr Eye Res. 2001;22(3):215-20. http://dx.doi.org/10.1076/ceyr.22.3.215.5516

9. Ornek K, Karel F, Buyukbingol Z. May nitric oxide molecule have a role in the pathogenesis of human cataract. Exp Eye Res. 2003;76(1):23-7. http://dx.doi. org/10.1016/S0014-4835(02)00268-3

10. Fu S, Dean RT, Southan M, Truscott RJW. The hydroxyl radical in lens nuclear cataractogenesis. J Biol Chem. 1998; 273(44):28603-9. http://dx.doi.org/10.1074/ jbc.273.44.28603

11. Ramar M, Raman T, Sivagnanam B, Ganapasam S, Munuswamy A. Curcumin prevents free radical-mediated cataractogenesis through modulations in lens calcium. Free Radical Biology \& Medicine. 2012;48(4):483-92.

12. Kabir N, Umar Al, Kabir H, Usman MM. Evaluation of in vitro aldose reductase inhibition potentials of aqueous leaf extracts of Momordica balsamina and Leptadenia hastate International Journal of Chemical and ttillil Natural Science. 2016;4(3):416-19.

13. Kinoshita JH. A thirty-year journey in the polyol pathway. Exp Eye Res. 1990;50(6):567-73. http://dx.doi.org/10.1016/0014-4835(90)90096-D

14. Guzmán 1A, Guerrero RO. Inhibition of aldose reductase by herbs extracts and natural substances and their role in prevention of cataracts. J Rev Cubana Plant Med. 2005:10:3-4

15. Patel DK, Kumar R, Kumar M, Sairam K, Hemalatha S. Evaluation of in vitro aldose reductase inhibitory potential of different fraction of Hybanthus enneaspermus Linn F. Muell. Asian Pacific Journal of Tropical Biomedicine. 2012b;18:134-9. http://dx.doi.org/10.1016/S2221-1691(11)60207-4

16. Akinmoladun AC, Ibukun EC, Dan-Ologe IA. Phytochemical constituents and antioxidant properties of extracts from the leaves of Chromolaena odorata. Sc Res Essays. 2007;2(6):191-4.

17. Moronkola DO, Adedeji DA, Oyewole IO, Ogunwande IA, Oladosu IA. Survey and Accounts of Anti-Malaria Ethnomedicinal Herbs Used In South-Western Nigeria and Vector Repellant Activities of Their Vo- latile Oils, The African Network for Drugs and Diagnos-tics [ANDI], 2nd Stakeholders Meeting \& Conference, Medical Research Council [MRC], Cape Town. 4-7 October, 2009

18. Cardon D, Jarsen PCM. Philenoptera cyanescens (Schumach. \&Thonn.) Roberty," In: P. C. M. Jarsen and D. Cardon, Edtor. PROTA 3: Dyes and Tannins/Colorants et Tannins, PROTA, Wageningen, 2005

19. Schrire BD. A Synopsis of the Genus Philenoptera (Leguminosae millettieae) from Africa and Madagascar". Kew Bulletin. 2000;55(1):81-94. http://dx.doi. org/10.2307/4117762

20. Dorcas OM, Ibrahim AO. Chemical Compositions of Lonchocarpus cyanescens Benth., (Fabaceae)-Case Study of Its Volatile Oils, and Two Triterpenoids American Journal of Plant Sciences. 2013;4(8):1653-9.

21. Irvine FR. Woody Plants of Ghana, with Special Ref- erence to Their Uses. Oxford University Press, London. p. 868;1961.

22. Perkin AG, Thomas F. RSC Publishing Paper XC. Indican, Part II," Journal of the Chemical Society, Transactions. 1999;95:793-807. http://dx.doi.org/10.1039/ CT9099500793

23. Burkill HM. Useful Plants of West Tropical Africa," Royal Botanic Gardens Kew, 3, 1985.

24. Hayman S, Kinoshita JH. Isolation and Properties of Lens Aldose Reductase. J Biol Chem. 1965;240(2):877.

25. Halder N, Joshi S, Gupta SK. Lens aldose reductase inhibiting potential of some indigenous plants. J Ethnopharmacol. 2003;86(1):113-6. http://dx.doi. org/10.1016/S0378-8741(03)00052-7

26. Stosceck CM. Quantitation of protein. Met In Enz. 1990;182:50-69. http:// dx.doi.org/10.1016/0076-6879(90)82008-P

27. Lowry $\mathrm{OH}$, Rosebrough NJ, Farr AL, Randall NJ. Protein measurement with folin phenol reagent. J Biol Chem. 1951;193:265-75.

28. Hemalatha S, Lalitha P, Arulpriya P. Antioxidant activities of the extracts of the aerial roots of Pothosaurea (Linden ex Andre). Der Pharma Chemical 2010;2(6):84-9.

29. Decker EA, Welch B. Role of ferritin as a lipid oxidation catalyst in muscle food. J Agricul Food Chem. 1990;38:674-7. http://dx.doi.org/10.1021/jf00093a019

30. Yu W, Zhao Y, Shu B. The radical scavenging activities of Radix puerariae isoflavonoids: a chemiluminescence study. Food Chem. 2004:86(4):525-9.http:// dx.doi.org/10.1016/j.foodchem.2003.09.005

31. Garrat DC. The quantitative analysis of drugs, vol. 3. Chapman and Hall Ltd., Japan, p.456-458, 1964. http://dx.doi.org/10.1007/978-1-4613-3380-7_1

32. Ruch RJ, Cheng SJ, Klaunig JE. Prevention of cytotoxicity and inhibition of intracellular communication by antioxidant catechins isolated from Chinese green tea. J Carcinogen. 1989;10(6):1003-8. http://dx.doi.org/10.1093/carcin/10.6.1003
33. Oyaizu M. Studies on products of browning reactions: antioxidant activities of products of browning reaction prepared from glucose amine. Jap J Nutri. 1986;44:307-15.http://dx.doi.org/10.5264/eiyogakuzashi.44.307

34. Harborne JB. Phytochemical Methods. Chapman and Hall td., London; 49-88, 1978.

35. Sofowara A. Medicinal plants and Traditional medicine in Africa. Spectrum Books Ltd, Ibadan, Nigeria; 191-289,1993.

36. Trease GE, Evans WC. Pharmacognosy. Bailliere Tindall London, Edn 11: 45-50, 1989.

37. Savithramma N, Linga Rao M, Suhrulatha D. Screening of Medicinal Plants for Secondary Metabolites Middle-East Journal of Scientific Research. 2011:8(3):579-84

38. Bemis DL, Capodice JL, Gorroocurn P, Katz AE, Buttyan A. Anti-prostate cancer activity of -carboline alkaloid enriched extract from Rauwolfia vomitoria. Inter J Oncol. 2006;29:1065-73. http://dx.doi.org/10.3892/ijo.29.5.1065

39. Campbell JI, Mortensen AA, Molgaard P. Tissue lipid lowering-effect of a traditional Nigeian anti-diabetic infusion of Rauwolfia vomitoria foliage and Citrus aurantium fruit. J Ethnopharmacol. 2006:104(3):379-86. http://dx.doi.org/10.1016/ j.jep.2005.12.029

40. Jun YU, Yan M Jeanne Drisko OC. Antitumor Activities of Rauwolfia vomitoria Extract and Potentiation of Carboplatin Effects against Ovarian Cancer. Current Therapeutic Research. 2013;75:8-14. http://dx.doi.org/10.1016/j.curtheres. 2013.04.001

41. Balasundram N, Sundram K, Samman S. Phenolic compounds in plants and agriindustrial by-products: antioxidant activity, occurrence, and potential uses. Food Chem. 2006;99(1):191-203. http://dx.doi.org/10.1016/j.foodchem.2005.07.042

42. Bunea $\mathrm{Cl}$, Pop N, Babes AC, Matea C, Dulf FV, Bunea A. Carotenoids, total polyphenols and antioxidant activity of grapes (Vitisvinifera) cultivated in organic and conventional systems. Chem Central J. 2012;6(1):66-74. http://dx.doi.org/10.1186/1752-153X-6-66

43. Pérez-Jiménez J, Arranz $S$, Tabernero $M$, Díaz-Rubio ME, Serrano J Go-i I, et al,. Updated methodology to determine antioxidant capacity in plant foods, oils and beverages: Extraction, measurement and expression of results. Food Res Int. 2008:41(3):274-85. http://dx.doi.org/10.1016/j. foodres.2007.12.004

44. Rababah TM, Banat F, Rababah A, Ereifej K, Yang W. Optimization of extraction conditions of total phenolics, antioxidant activities, and anthocyanin of oregano, thyme, terebinth, and pomegranate. J Food Sci. 2010;75(7):626-32 http://dx.doi.org/10.1111/j.1750-3841.2010.01756.x

45. Farhan MB, Razak AP, Kar Y, Zamree MD, Shah LC, Abdullah, et al. The Effects of Varying Solvent Polarity on Extraction Yield of Orthosiphon stamineus Leaves. Journal of Applied Sciences. 2012:12:1207-10. http://dx.doi.org/10.3923/jas.2012.1207.1210

46. Pin KY, Chuah AL, Rashih AA, Mazura MP, Fadzureena J, Vimala S, et al. Antioxidant and anti-inflammatory activities of extracts of betel leaves (Piper betle) from solvents with different polarities. J Trop For Sci. 2010;22:448-55.

47. Ajani EO, Salako AA, Sharlie PD, Akinleye WA, Adeoye AO, Salau BA, et al. Chemopreventive and remediation effect of Hydrocotyl bonariensis Comm Ex Lam (Apiaceae) leave extract in galactose-induced cataract. Journal of Ethnopharmacol. 2009;123(1):134-42. http://dx.doi.org/10.1016/j.jep.2009.02.006

48. Jung HA, Yoon NY, Kang SS. Inhibitory activities of prenylated flavonoids from Sophora flavescens against aldose reductase and generation of advanced glycationend products. J Pharm Pharmacol. 2008;60(9):1227-36. http://dx.doi. org/10.1211/jpp.60.9.0016

49. Patel DK, Kumar R, Sairam K, Hemalatha S. Pharmacologically tested aldose reductase inhibitors isolated from plant sources-A concise report Chinese Journal of Natural Medicines. 2012a;10(5):0388-92.

50. Urszula Z, Sylwia M, Małgorzata N, Michaet S. The effect of different solvents and number of extraction steps on the polyphenol content and antioxidant capacity of basil leaves (Ocimum basilicum L.) extracts. Saudi Journal of Biological Sciences in press. 2015.

51. Kato A, Yasuko $\mathrm{H}$, Goto $\mathrm{H}$. Inhibitory effect of rhetsinine isolated from Evodia rutaecarpa on aldose reductase activity. J Phytomedicine. 2009:16(2-3):258-61. http://dx.doi.org/10.1016/j.phymed.2007.04.008

52. Mutiu IK, Theophilus CD. Hypoglycaemic potential of leaf extracts of Lonchocarpus cyanescens (Schum and Thonn) Benth. Transaction of the Royal Society of South Africa. 2015;71(1):1-6

53. Copeland RA. Evaluation of Enzyme Inhibitors in Drug Discovery: A Guide for Medicinal Chemists and Pharmacologists. Wiley, New York. p. 243-147, 2005

54. Michalak A. Phenolic Compounds and Their Antioxidant Activity in Plants Growing under Heavy Metal Stress. Polish J of Environ Stud. 2006;15(4):523-30.

55. Catherine R, Nicholas M, Geaoege P. Antioxidant properties of phenolic compounds. Trend in Plant Science. 1997;2(4):152-9. http://dx.doi.org/10.1016/ S1360-1385(97)01018-2

56. Zhang HY, Sun YM, Wang XL. Substituent effects on $\mathrm{O}-\mathrm{H}$ bond dissociation enthalpies and ionization potentials of catechols: A DFT study and its implications in the rational design of phenolic antioxidants and elucidation of structureactivity relationships for flavonoid antioxidants. Chem Eur J. 2003:9(2):502-8. http://dx.doi.org/10.1002/chem.200390052 
57. Amarowicz R, Pegg RP, Rahimi-Moghaddam P, Barl B, Weil JA. Free-radical scavenging capacity and antioxidant activity of selected plant species from the Canadian prairies. Food Chem. 2004,84(4):551-62. http://dx.doi.org/10.1016/ S0308-8146(03)00278-4

58. Moure A, Cruz JM, Franco D, Domínguez JM, Sineiro J, Domínguez
$\mathrm{H}$. Naturalantioxidantsfrom residualsources. Food Chem. 2001;72(2):145-71. http://dx.doi.org/10.1016/S0308-8146(00)00223-5

59. Anjali S, Sheetal P. Phytochemical Analysis and Free Radical Scavenging Potential of Herbal and Medicinal Plant Extracts. Journal of Pharmacog and Phytochemistry. 2013;2(4):22-9.

Cite this article : Ajani EO, Sabiu S, Odufuwa KT, Ibrahim TB, Salau BA. Evaluation of Lens Aldose Reductase Inhibitory and Free Radical Scavenging Potential of Fractions of Lonchocarpus cyanescens: Potential for Cataract mediation . Pharmacog J. 2017;9(1):62-9. 